\title{
Political Public Relations - Media and Information Management
}

Professional paper _ UDK 32.019.5:659.441.8 _ Received on 26 March 2016

\section{Zoran Tomić}

Faculty of Humanities and Social Sciences, University of Mostar, Bosnia and Herzegovina. Email: zoran.tomic@sve-mo.ba (corresponding author)

\section{Ivana Grbavac}

Faculty of Humanities and Social Sciences, University of Mostar, Bosnia and Herzegovina.

Email: ivana.grbavac@tel.net.ba

\section{Abstract}

Political public relations, as one of the PR programmes, has slowly created strategies and tactics for communication with the public and the media. Media management and information management are the most important activities of the political public relations. These activities are frequently connected with non-ethical communication, whose aim is media manipulation and manipulation of the public. Media manipulation is well known as communication spin. These activities are created by government and political communication specialists, referred to as spin doctors. The paper analyzes several spin techniques of the government PR. Although there are signs of manipulation, political PR specialists claim that it is "acceptable" communication that is in the "interest" of the organization and the public.

Keywords: political public relations, information, media, management, communications, image, spin doctor 


\section{Introduction}

Back in 1967 Hannah Arendt wrote in her book Truth and Politics that nobody ever doubted that truth and politics were in pretty poor relations. According to her, the love of truth was never considered a political virtue. It is not only politicians and demagogues who have always thought that lies were necessary and justified - lies were also being used by state officials.

Has politics changed in the meantime? How much have contemporary PR practitioners helped the (new) politics and its transparency? Are they indeed persons responsible for bidirectional communication and interpreters of often entangled politics? Or, as Arendt puts it, are they people who persuade us that the "sun is shining when it is pouring rain?". This paper will try to answer those and numerous other questions.

\section{Defining political public relations}

Political public relations is a managing process through which political actors, for political reasons, with the help of efficient communication and activities, try to influence, build and maintain good relations and reputations with the target public in order to support the mission and achieve political goals (Strömbäck, Kiousis, 2011, p. 8).

There are not many definitions of political public relations. This definition can be compared to the two definitions of political public relations given by Astrid Zipfel and Brian McNair. According to Zipfel "political public relations refers to the strategic communication activities of actors participating in the political process that aim at informative and persuasive goals in order to realize single interests" (as cited in Strömbäck, Kiousis, 2011, p. 8). “This definition considers political public relations communication as a unidirectional phenomenon and expresses the functional perspective of political public relations." (Strömbäck, Kiousis, 2011, p. 8) Therefore, it is not the transfer towards creative public relations perspective that was an indicator in public relations research during the last decades (Botan, Taylor, 2004 as cited in Strömbäck, Kiousis, 2011, p. 8). On the contrary, it is believed that the relational perspective is crucial for the understanding of all processes that include politics, communication and public relations (Strömbäck, Kiousis, 2011, p. 9). In other words, Jesper 
Strömbäck and Spiro Kiousis concluded that Zipfel's definition was biased towards the functional perspective, which is becoming outdated (2011, p. 9).

McNair (as cited in Strömbäck, Kiousis, 2011, p. 9) also offered a definition of political public relations. According to him, political public relations is tactics of media and information management whose aim is to ensure that the party gets maximum favorable publicity and minimum negative publicity. This definition does not have much in common with the contemporary understanding of public relations, but it is typical and shows how political communication scientists often see public relations (Strömbäck, Kiousis, 2011, p. 9). According to this view, public relations mostly consists of media management, image management and information management (Strömbäck, Kiousis, 2011, p. 8). However, this is a very narrow view of public relations. But the given definition reflects the contemporary understanding of public relations and it is adjusted to the context of politics and political communication. It highlights the communication of politics and the efficient nature of communication for political purposes. It has the potential of integration of theory and research from different research areas. Also it includes different PR functions that are often emphasized in papers, such as publicity management, reputation management, public affairs management, questions management and maintaining good relations.

\section{Activities of political public relations}

Public relations officers have different functions in the government because state institutions are present at all layers of society. The public must be informed about what is going on in the government structures, which is the foundation of every democratic society, but at the same time politicians must have an insight into public opinion. The state must provide society with everything that an individual cannot realize. In order to do that, it has to listen to the needs of society.

Activities of public relations in modern political parties and governments are a mixture of marketing and propaganda (Baines, Jefkins, 2004, p. 379). This view of PR activities means that the political actors often want to persuade people in the sense of political ideas and contents by using a one-way, manipulative communication process. However, no matter whether public relations in politics is unidirectional or bidirectional, it should be emphasized 
that public relations is a legitimate activity used for the purpose of explaining official politics to citizens and other actors in the political communication process.

There is an old thought which says that while in a society there are leaders, there will be a mutual relation of love and hate between the rulers and the ruled. It is not easy for any political person or organization to manage or to serve in the context of constant conflicts. Nowadays, many Americans are angry with government institutions and they feel alienated from the government and political creation process.

"A weak connection between citizens and their government is obvious: voter turnout is smaller at all levels, public debates are often rough, humiliating and fierce, the us vs. them mentality influences meetings in city halls, public hearings and other open forums. Public opinion polls show that more than $75 \%$ of Americans have little or no faith that their local government can solve problems. An even larger percentage believe that the government of their state or the federal government cannot solve the problems that affect their lives." (Cutlip, Center, Broom, 2003, p. 513)

Being aware of these facts, the political actors nowadays use different communication "mixtures" in order to achieve the goal of political communication - the persuasion of the public. In this process of persuasion, public relations is being included more and more. They stand between the politicians and the media, gaining profit from their interdependence. It seems that this relationship was best depicted by Bernard Ingham, ex media secretary of the Prime Minister of Great Britain Margaret Thatcher. He presented the mutual dependence of the politicians and the media as a cannibalistic relationship, claiming that "they feed on each other so that you never know who is next on the menu" (Somerville, 2002, p. 30).

Spreading the influence of public relations onto daily relations between the political institutions and the media, public relations became a "service industry" which makes political communication among parties, candidates and their public easier, which produces publicity and marketing materials and which conducts public opinion surveys. Lori Melton-McKinnon, John C. Tedesco and Tracy Lauder confirm the following: they write that communication is a link between public relations and politics. 
"After he [a politician] has all the prerequisites for the duty he is running for, his electoral fate depends on the quality of managing his communication with the public, especially with the media. Actually, the task of the expert is to try to wrap his political ideas into attractive paper and to put them onto market using different communication means.” (Melton-McKinnon, Tedesco, Lauder, 2001, p. 562)

In connection to this, McNair writes about four types of activities of political public relations: 1. media management; 2. information management; 3. image management and 4. internal communications of the organization (2003, pp. 129-130).

\subsection{Media management}

The first activity is media management. This activity consists of producing media suitable events that will probably draw attention of the media gatekeepers. The aim of media management is not only to keep an organization's presence public, but also to ensure that it is its definitions of political problems and solutions that are followed. The connection between politicians and media and, which is even more important, between government and media means a struggle between two interests with different directions (Somerville, 2002, pp. 25-26). A journalist should find and present facts, whereas a politician will make sure that the news presents a message that he wants to deliver. It is not a new phenomenon that the political elite tries to have control over media. In connection with this, some analysts point to the increased usage of the so-called soundbite and pseudo-events. If we add to these techniques the technique of spin, then we will get the three most important techniques that are being used in media management: soundbite, pseudo-events and spin. Practitioners believe that all political parties and all governments change information. The former director of research for John Major thinks that there is nothing wrong with that (Theaker, 2007, p. 54).

\subsection{Information management}

The second activity is information management. Every government that was elected in a democratic way has to communicate with its citizens/voters. It is its duty to provide the 
public with information, but this does not mean that it will not try to control and manipulate with the quantity and the kind of information it delivers. So, information is a powerful political weapon, and its selective dissemination, limiting and/or distortion done by the government are an important element in public opinion management.

The practice of public relations on the political territory in the USA is done by special political actions boards. Employees in different companies and members of different organizations can contribute to the more successful achievement of their political goals if they make a payment for the political action board. The boards use this money for providing support to political candidates and political parties as well as for different types of lobbing in order to achieve the set political goals of different interest groups. Additionally, through these boards, the employees achieve their right to get organized for the protection of their interests when negotiating with the company management.

\subsection{Image management}

The third activity is image management in political public relations. Image management can be seen as the personal image of an individual politician and ways to shape him so that he is suitable for the organizational aims. On the other hand, image management can be seen as the image of the political organization.

\subsection{Internal communication management}

The fourth type of political public relations activities are activities connected to internal communications of the organization. "That includes opening channels for the internal information flow, for the coordination of the activities and dealing with the back information." (McNair, 2003, p. 129) The analyses have shown that some of the huge failures of the political communications of some parties are due to inadequate public relations. Therefore, it is of crucial importance that political parties also develop efficient internal communication. Although such communication is usual in organizations, it has a special value in political organizations and governments for the two following reasons: 
1. because of the almost instant public dissemination of a statement, action or political manifesto, it is important that all members are aware of the current issues

2. rumors or half-truths can be harmful and counterproductive in every political organization (Broom, 2010, p. 417).

\section{Media and information management - techniques of government public relations}

We have already emphasized that every government elected in a democratic way has to communicate with its citizens/voters. As we could see from the example about American political action boards, the practice of political public relations in the world, even in the developed democracies, has a lot of techniques and tools that government public relations use. Some of these techniques are manipulative and as such dangerous for the media and the public (Richardson, 2002, pp. 172-173).

\subsection{Information access management}

Public relations professionals are asked on a daily basis for different information by journalists. In this communication, professional PR officers develop a strategy of mutual relations with journalists. Looking from this simple perspective onto their relationship, public relations has the task to manage information access. However, and more importantly, public relations is faced everyday with the challenge of media access limitations (Richardson, 2002, pp. 172-173).

When we talk about managing access in the political sphere, it can include occasional announcements of difficult information, kite-flying, spin of newspaper headlines or stimulating addiction of some journalists. As regards access limitations, PR professionals sometimes go so far in their attempts to stop making information public that they obstruct access of journalists to political leaders, they hide scoops, scandals, they limit access to conventional reporters and refuse negative stories (Davis, 2006, p. 39).

Modern and educated PR officers will never say to their source that they are not giving them sensitive information. They are obliged by the law to do so. These persons know very well 
about the deadlines of the journalists and they know their methodology. They will simply play the stalling game. At the end of the day, they offer a little bit of truth, so that the journalists, realistically, do not have time to fix it. To put it simply, political public relations very often becomes the guard of their leaders. It should be highlighted that such secrecy of information is a form of media pressure (Davis, 2006, p. 39).

\subsection{Time limit}

The time limit is a simple tactic that is used very often and has good effects. The purpose of this means of political public relations is the following: the government communicates the information as late in the day as possible, so that the evening news, radio and TV do not have all elements of the story public, or do not receive real critical objections from the opposition and the media public. Political public relations experts think that this tactic is especially useful for the situation when the government believes it could be attacked by the opposition, the media, NGOs or lobby groups. The time limit tactic enables the government to buy some time, it allows it to better prepare for reactions, and it has the effect of the first information. Very often it is used even after closed government meetings (Richardson, 2002, p. 173).

Journalists find that this tactic of news management can produce a boomerang effect and unintended consequences. It can backfire on the government. The media might, after the analysis of the material, find that the government tried on purpose to avoid a detailed examination of the problem. The time limit tactic may cause a provocation and prompt an even more detailed story the next day. However, in spite of the negative connotations, government public relations will continue to use this tactic.

\subsection{Information leaking}

When we study the practice of political public relations and political communication, we can talk about two types of information leaking: controlled and uncontrolled information leaking. Both lead to making news public before the others. Or it should be so. Managing information leaking can be an efficient way for the government to announce selectively what it thinks 
is high potential information (Street, 2003, p. 96). Uncontrolled leaking or real leaking is still considered to be a sign of good journalism (Richardson, 2002, p. 174).

When we have the case of controlled information leaking, it is in the best interest of the government or the party to manage such information via prominent journalists. Although they will be using the information on background or on deep background, i.e. in off, the credibility of the prominent journalists and their relation to the editors will guarantee that the information will be accepted. On the other hand, when we have uncontrolled leaking, it is asking for the prominent journalist's authority too. If uncontrolled information from reaches younger journalists, it will be quite difficult for them to convince the editors of the accuracy of the source of information.

While controlled information leaking is a strong political public relations means (Franklin, 2006, p. 60), uncontrolled information leaking is the most popular from the Watergate affair. It is well known that, in 1971, Richard Nixon authorized a special research unit in the White House, which was named plumbers. The task of the unit was to stop the leaking of confidential information (Journalists of The New York Times, 1974, p. 65).

\subsection{Freezing}

In democratic societies, media laws and laws on access to information enable journalists unhindered freedom of access to government information. In accordance to those laws, governments must not only make information available "within a reasonable time limit", but also establish infrastructure which makes the information accessible. But regardless of the legal framework, is all information really accessible to all journalists under the same conditions? Media analysts and PR practitioners are well aware of the possibility of freezing information (Richardson, 2002, pp. 174-175).

Freezing is in fact a form of penalty imposed by government's PR or government officials on the media whose reporting is perceived by the government as tendentious, non-objective, critical or biased. It is additionally accompanied with the threat of isolating the journalists. Freezing is a sensitive technique in the work of political public relations. It is occasionally effective, particularly when implemented upon younger, more inexperienced journalists. In 
certain occasions, freezing has caused dissidences and problems among prime ministers, governments and media owners.

\subsection{Dispersion}

The technique of dispersion is frequently employed by government public relations. The government attempts to frighten and silence the journalists or at least provoke alternative (government) opinions amongst the reporters. A common form of dispersion is when a politician or his/her secretary makes direct telephone calls to journalists. These phone calls usually end with a promise of imposing the freezing technique (Richardson, 2002, pp. 174-175). Pressuring journalists by using the technique of dispersion is still in existence. In order to amortize these pressures, journalists must be unequivocally professional, mature and reasonable, all of which require courage and maturity, and as some suggest, a good sense of humor.

\subsection{Carrot and stick}

Many governments play the old-fashioned game of carrot and stick. Unfortunately, the stick is more common than the carrot. In October 1997, Alastair Campbell sent a stronglyworded note to all information managers of the Government's Department of Information and Communication, claiming that relations towards the media must be more energetic. "Choose your cover, sell your story, and if you disagree with what is written, defend your case. If you need the support of headquarters, let me know.", wrote Blair's spin doctor. Ever since, the relations towards journalists who have reported disregarding the government's restrictions have become extraordinarily difficult. "Journalists were privately harassed, publically and harshly persuaded and excluded from unofficial briefings. There are only a handful of journalists which Campbell has not attempted to harass or humiliate." (Franklin, 2006, p. 51) The Labour party's spin doctors have never hesitated to destabilize journalists by speaking to their superiors behind their backs. The most famous case was that of Andrew Marr, a close ally of the Labour party and editor of the Independent at the time. Marr wrote a critical article about the Labour Party's European politics, after which Campbell hastily contacted David Montgomery, executive editor of the Mirror Group Newspapers, which owned 
the Independent, demanding that Marr be laid off. Campbell said to Marr: "You are either with us or against us.” (Franklin, 2006, p. 51)

\subsection{Wedge}

The wedge technique is known as the divide and conquer or division and victory principle, and it is similar to freezing. This technique is simple in its intention and execution. Government deteriorates the relationship (drives a wedge) between the media or journalists. A part of the strategy can be preferential treatment towards one print media, or favoring relationship towards one print media as opposed to another (Franklin, 2006, pp. 59-60). This tactic can cause animosity between those who are excluded and the favored (Richardson, 2002, pp. 176177). This approach allows political public relations to support commentators or journalists who are believed to report in accordance to the government's views. In this way, politics uses individuals as a basis for driving wedges between people and increasingly, the Press Gallery itself. Analysts consider this a model of creating "Them" and "Us". The wedge tactic is the government's endeavor to outwit the staff in the Press Gallery, by demonstrating closeness toward those journalists who, for ideological or personal reasons, report the government's messages. These journalists are the government's “warders”, and their strategy is to obtain messages "under the table" (Richardson, 2002, pp. 176-177).

\subsection{Dripping}

Dripping is a technique that allows access to information directly from the government. The core of this approach is delivering information from highly ranked politicians to the journalists and commentators who are believed to be inside the government's tent (those who are loyal). Dripping is another simple and efficient way to ensure journalist's loyalty to the government. As long as the government can use the wedge technique to create animosity in the gallery, dripping is a technique that attracts prominent editors and journalists to the government's circle (Richardson, 2002, pp. 177-178). Dripping is an efficient way for the government's PR to promote its message, because the government chooses renowned and highly ranked journalists. This tactic strives to get those reporters "on the other side" off 
the drip. The difference between drip and leaking is that drip is usually a sequence of small leakages over a longer period of time. The media wants to be on the drip because they desire privileged access and information (Richardson, 2002, pp. 177-178).

The drip is usually enabled only to those higher ranking journalists of political motley, who reflect the government itself. Therefore, the mere call for journalists to receive the drip is a status approval (confirmation). The status rapidly improves when colleagues read or see the results of a fellow journalist who is on the drip. There are numerous political journalists that are off the drip and are not inclined to approve of those who are. They believe that their job is to be strictly independent and to obtain information from different sources, rather than accept the government's views, no matter how exclusive the information might be.

\subsection{Bonding}

Relying on the experiences of Vietnam, British Prime Minister Margaret Thatcher had initially intended to exclude the media from reporting about the 1982 British Royal Navy's mission to free the Falklands. Being pressured by those editors of the Fleet Street who once ensured support to Mrs. Thatcher, she changed her mind and allowed 29 journalists to report on the army - and they were all British. ${ }^{1}$ These 29 journalists experienced the phenomenon of socalled bonding with the troops with whom they shared accommodation on ships. Before the British forces reached the battlefield, the mutual feeling of identification between the people who shared food, drinks and accommodation for weeks, had already been formed. When the ship censors asked of $\mathrm{BBC}$ reporter Brian Hanrahan not to mention the number of airplanes that took off from airplane carrier - for security purposes - he complied with reporting with the now famous sentence: "I counted them all out, and I counted them all back." (Taylor, 2003, p. 74) He did not disclose information about the ship's location, but instead mentioned a successful mission without casualties, which increased morale back at home. In a nutshell, the whole experience was the Army's attempt to present the views from one side, which was a favorable view of war with actually very little bloodshed. As one ITN reporter was told by a PR official: "Prior to coming here, they informed you that negative reporting is not allowed. When you arrived, you knew you were expected to do the job of promoting, like in 1940."

1 Foreign media were supposed to take information from Reuter reporters. 
The method or a phenomenon of bonding is recorded in the media coverage of events taking place at Tiananmen Square in China. Namely, the journalists had spent a lot of time in the company of protesting students, and they had very little contact with the Chinese officials. Perhaps that explains the fact why such a great number of reporters accepted the student's perspective of the conflict. A similar phenomenon happened in Israel during the protests of the evacuation of Yamit on Sinai - the reporters and protest leaders spent a lot of time together, hence they developed a symbiotic relationship which surpasses the regular relationship between journalists and the source (Wolfsfeld, 2003, pp. 90-91).

\subsection{Agenda}

The agenda is the government's attempt to impose on the media what they perceive as the most important news of that day. It is often led by the political imperative and as such it is a part of the government's flexible strategy to minimize political problems by finding ways to raise political noise or distract the media's focus. Imposing the political agenda is a challenge on one side, as well as a routine job on the other. Politicians want to shape the atmosphere of positive opinions about political discussions and topics (Franklin, 2006, p. 47). If political public relations does not manage to succeed in it, then they resort to revealing some other juicy detail, such as the private life of the president or prime minister. The technique is especially used by Nikolas Sarkozy's spin doctors. According to British newspaper The Guardian, when the media writes about the bad political moves of Sarkozy, it is immediately presented with a story about Carla Bruni and him. If used regularly, such stories push hard politics in the background. The best media tactic, in this case, is to try to understand what the government is doing and why it is attempting to divert attention. Many experienced political commentators instinctively know when a certain item on the agenda is used to smooth out the potentially damaging political noise and therefore, such journalists adhere to their original story.

Nevertheless, the media are predictable. Because of its fresh appeal, the most prominent news of the day in the electronic media will more likely be about the new daily agenda then old stories. However, there is an exception that occurs when the media actually plans to raise political noise which causes changes in the agenda. In this case, as an extension of the original story, the media can report about the government's attempts to change the public's focus. 


\subsection{Place (meeting point)}

Experiences of the overseas leaders influence this communicative tactic which strives to isolate the prime minister from the usual media context and place him in the appropriate - presidential - environment, one suited to his status. The intention - most efficiently used by the President of the United States when he dared to stand on the White House lawn - is to place a government official in the prime minister's courtyard, where he could come and leave whenever he wants. This of course, eliminates any sort of prime minister's appearance as a hostage of media's interrogations. It also intensifies the role of television as a media which documents and enhances the role of image (Richardson, 2002, p. 180).

\subsection{Briefing}

This tactic was developed to ensure that the government delivers its message directly to the media in the most efficient way. Briefings on the highest level - between presidents, prime ministers and editors - began before World War II. The most transparent example of briefing is the state budget. Before budget discussions, Prime Minister may summon journalists for a briefing, who will be accompanied by bureaucrats from the Ministry of Finance, who help to fill the gaps in media knowledge and explain numerous graphic illustrations and data (Richardson, 2002, pp. 177-178). A common trait of these briefings in the West - as well as to all dialogues of this nature - is that nobody can get quoted, which is partially due to the fact that many of these discussions occur with state officials who, as unelected functionaries, are not allowed to speak about politics publically.

The media is experienced enough to know the rules of engaging in this form of communication. They mostly play by the rules of anonymity because the information that is provided helps reporters to understand more and appear more informed. In fact, there are many beneficial reasons for briefing on both sides of the "political fence" if everybody plays by the rules.

A typical Government communication day in Great Britain during Tony Blair's mandate started at 9 a.m. with a meeting of all members of the government's staff for communication, including Alastair Campbell, Jonathan Powell, the Prime Minister's Chief of Staff, advisors from the Department of Finance and the Deputy PM's office, as well as the representatives of 
Cabinet Ministries (Franklin, 2006, p. 49). The aim of the meeting was to ensure agreement in representation strategy and to entrust certain individuals with managing all presentations that day. The Labourites' determination to control all messages meant that nothing could be left to chance. Messages had to be carefully written, practiced in detail and unanimously supported by the Party and the Government, while the Central government coordinated them. The messages had to be favorably represented in the media (Franklin, 2006, p. 49).

A significant number of new institutions (established after 1997) were entrusted with key roles in managing relationships between politicians and journalists. The Department for Media Monitoring was entrusted with preparing a daily news review and finding potential problematic issues that needed to be rebuked at morning communications meetings taking place before the journalist briefing at 11 a.m. (Franklin, 2006, p. 49).

\subsection{Hook}

Promotion through objects is an important part of marketing appeal to the clients, whereas business gifts are signs of appreciation (Tomić, 2012, pp. 389-399). That is how the logic of business gifts works in principle. Political communication and public relations practitioners accepted this political principle, in addition that political PR adds a certain amount of spin (Tomić, 2010, p. 149).

In his book Éthique de l'information, Daniel Cornu writes: small gifts are a weak spot of the journalist profession. Companies, agencies and different organizations plan funds for small gifts to journalists in their budgets. Journalists are presented alluring offers in order to persuade them into publishing a certain article or some convenient and beneficial information (1999, p. 42). Thus, we enter the world of manipulation. In order to avoid these communication hooks (gifts), the state introduces laws for its officials regarding conflict of interest in governmental institutions, while PR organizations introduce their codices in which they demand avoidance of such activities. Laws regarding conflict of interest instruct executive officials and advisors who perform public jobs to act responsibly and conscientiously in order not to jeopardize citizens' trust, and to respect legal and other regulations which determine the rights, commitments and responsibilities in performing public functions. In performing public services, elected officials must act according to the ethics of their profession and function which they perform. 
In the context of these laws, a gift stands for any payment, favor or object of value, given or done to the receiver, without expected remuneration in return. Gifts received from family members and other persons or institutions cannot exceed 400 kunas for example.

Government public relations frequently resort to distributing small business gifts to journalists who report daily about their work. The logic of government PR is to create trust and subsequently, obligation. Consistent present giving can create a feeling of indebtedness, which PR employees know how to exploit at the right time. Gifts that are used to create the feeling of indebtedness are called hooks.

\subsection{Closed government sessions}

A governmental spin tactic is closed government sessions (Tomić, 2012, p. 390). In that way, governments attempt to spread information which could compromise them in public. Commonly, the media, (especially electronic) briefly attend the session opening, and then wait for the government's PR Department to issue a press release. Media, as well as opinion makers, often accuse governments of not being transparent and of covering up information, or in other words - that they are using spin techniques. Undoubtedly, there is room for spin in such sessions. However, numerous analysts believe governments will continue to use this technique of information management, regardless of all criticisms.

\subsection{Spin}

Spin is the most praised and reprehended tool in terms of government-media relations. Every government uses it, including the opposition. Political will over media can be manifested through media regulations, state control over media, information secrecy, pressuring the media, etc. Political parties and governments are visible sources of pressures on journalists. There are many reports on how governments and ministries affect media content in their reports. They influence the media through media experts and spin doctors (Street, 2003, pp. 125-128).

Spin doctors are people responsible for shaping positive public perception about politicians or political parties by skillfully manipulating the mass media. Those people can be personal 
advisors of politicians, and often a confidential friend. Spin doctors know how the media operates, the specific characteristics of media, and they also frequently come from the media realm into politics. They have excellent connections with editors, particularly the most influential ones. Spin doctors depend on the media, and the media depend on spin doctors. They have the goods, the information that is the life of the media (Tomić, 2010, p. 147).

One of the roles of spin doctors is to give anonymous guidelines about the actual meaning of certain events, actions or statements, as well as to influence interpretations. Many spin doctors used to be journalists and therefore they know how the media functions. They are aware of journalists' dependence on deadlines and they are always ready to provide information. Of course, they are seeking to get positive texts for their superiors, and minimize the negative ones (Richardson, 2002, p. 179).

\section{Conclusion}

Political public relations is a process through which political protagonists seek to affect, establish and maintain good relations and reputations with the target audience by using effective communication strategies and activities for the purposes of ensuring support and gaining political goals. Government PR experts perform various roles, as state institutions are present in all structures of society. As the public must be informed about current political events, politicians must have insights into public opinion. Political protagonists today use various communication mixtures in order to successfully accomplish the goal of political communication - persuasion of the public. In persuasion processes today, we refer to different political activities of public relations. Those are: media management, information management, image management, and internal communication organizations.

PR professionals are exposed to telephone calls and inquiries and contacted in order to obtain information on a daily basis. In such communications, PR professionals develop strategies of mutual relationships with journalists. If we look at their relationship through a simple prism, public relations boils down to managing access to information. But more importantly, public relations officials are regularly challenged in ensuring limited media access. 
Modern and well-educated public relations staff will never admit that certain, sensitive information is not being disclosed, because they are legally bound to do so. These professionals are well aware of journalist deadlines and the methodology of their work; therefor they simply stall in order to put journalists in a position of fighting deadlines. That kind of "game" influenced the development of government's PR techniques and strategies. Journalists often consider government's PR experts as manipulative, and government's PR experts frequently characterize media as manipulative.

\section{Reference List}

- Baines, P., Egan, J., Jefkins F. (2004). Public Relations - Contemporary Issues and Techniques. Burlington: Elsevier.

- Cornu, D. (1999). Etika informisanja. Beograd: Clio.

- Cutlip, S. M., Center, A. H., Broom, G. M. (2003). Odnosi s javnošću. Zagreb: MATE.

- Cutlip, S. M., Center, A. H., Broom, G. M. (2010). Učinkoviti odnosi s javnošću. Zagreb: MATE.

- Davis, A. (2006). Public Relations and News Sources. In: Cottle, S. (Ed.), News, Public Relations and Power (pp. 27-44). London: Sage Pub.

- Franklin, B. (2006). 'A good Day to Bury Bad News?': Journalists, Sources and the Packaging of Politics. In: Cottle, S. (Ed.), News, Public Relations and Power (pp. 45-62). London: Sage Pub.

- Journalists of The New York Times (1974). Kraj Predsjedništva. Zagreb: Stvarnost.

- McNair, B. (2003). Uvod u političku komunikaciju. Zagreb: FPZG.

- Melton-McKinnon, L., Tedesco, J., Lauder, T. (2001). Political Power Through Public Relations. In: Heath, R. L., Vasquez, G. (Eds.), Handbook of Public Relations. Thousand Oaks: Sage Pub.

- Richardson N. (2002). Playing political games: ministers, minders and information. In: Tanner, S. (Ed.), Journalism Investigetion \& Research. London: Longman.

- Somerville I., Wood, E. (2007). Public Relations, Politics and the Media. In: Theaker, A. (Ed.), Handbook of Public Relations (pp. 32-51). London and New York: Routledge.

- Street, J. (2003). Masovni mediji, politika i demokracija. Zagreb: FPZG.

- Strömbäck, J., Kiousis, S. (2011). Political Public Relations: Deining and mapping an Emergent Field. In: Strömbäck, J., Kiousis, S. (Eds.), Political Public Relations-Principles and Applications (pp. 1-32). New York: Routledge.

- Taylor, P. M. (2003). Journalism under Fire: The Reporting of War and International Crises. In: Cottle, S. (Ed.). News, Public Relations and Power (pp. 63-80). London: Sage Pub.

- Theaker, A. (2007). Priručnik za odnose s javnošću. Zagreb: HUOJ.

- Tomić, Z. (2012). Osnove političkog komuniciranja. Zagreb-Mostar: Synopsis.

- Tomić, Z. (2010). Politički odnosi s javnošću - strategija upravljanja informacijama. Medijski dijalozi, 3 (6), $139-152$.

- Wolfsfeld, G. (2003). The Political Contest Model. In: Cottle, S. (Ed.) News, Public Relations and Power (pp. 81-98). London: Sage Pub. 


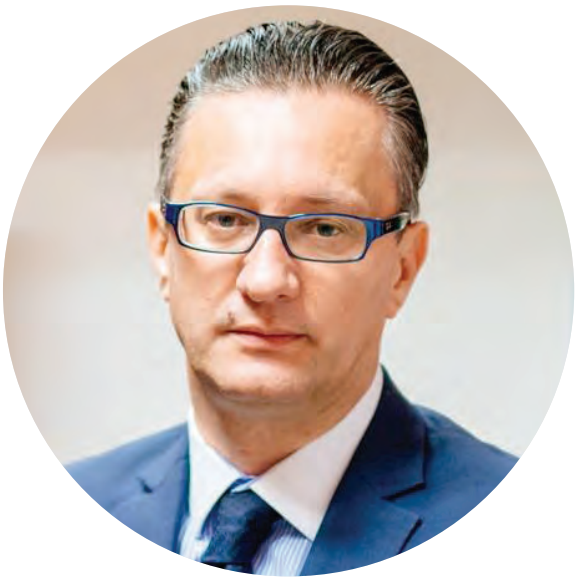

\section{Zoran Tomić}

Zoran Tomić is a full professor at the Faculty of Humanities and Social Sciences University of Mostar and the Head of Public Relations Department. He is a visiting professor at the University of Zagreb and University of Dubrovnik. His fields of interests are public relations, political communication and political marketing. He is the author of the first local textbook in public relations "Odnosi s javnošću - teorija i praksa”, 2008, 2016., as well as the author of the following textbooks "Osnove političke komunikacije” and "Politički marketing”. He has got several awards for his work.

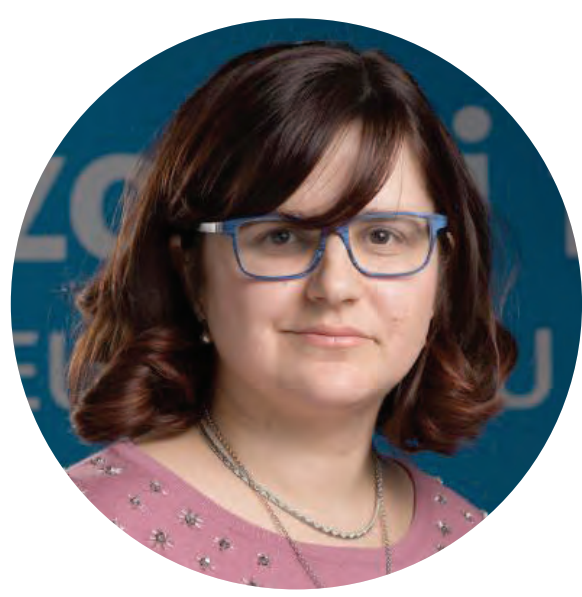

\section{Ivana Grbavac}

Ivana Grbavac, Assist. Prof., is a $\mathrm{PhD}$ in Linguistics. She is the Head of Department of English language and literature at the Faculty of Humanities and Social Sciences University of Mostar. Fields of her interest are communication, semantics and linguistic landscaping. 